\title{
Beyond Governmentality: Building Theory for Weak and Fragile States
}

\author{
By Priscilla Magrath (University of Arizona)
}

\begin{abstract}
Every discipline has its blind spots. In this discussion piece I suggest that International Development can help Anthropology address one of its blind spots, namely the problem of weak government. Whereas those working in international development encounter the effects of weak government in their daily work, anthropological theory offers limited analytical tools for these contexts. Rather than focusing on development's many failings, perhaps it is time for Anthropology to adopt a more constructive approach, drawing on the experience of development workers to develop anthropological theory which can speak to the condition of contemporary weak states.
\end{abstract}

\section{'At the end of the day, a government is necessary' \\ Afghan official, BBC Oct 182009}

\section{Introduction}

During twenty years of work in international development, ${ }^{1}$ I often encountered national governments by way of their limitations: the lack of data on populations; the failure to deliver services; the inadequate budgets; the low priority given to the welfare of populations. Embarking on a $\mathrm{PhD}$ in Anthropology would, I thought, provide the analytical tools necessary to make sense of my experience. But anthropological theory ${ }^{2}$, drawing on Western European philosophy and political history, appears focused on strong governments, highlighting the potential dangers of excessive government, rather than the challenges of weak government. Similarly, critiques of the development enterprise suggest that it is powerful, either pursuing donor interests in neo-colonial fashion (Escobar, 1995), or undemocratically

\footnotetext{
${ }^{1}$ By "international development" I refer to the use of aid by donor governments, multilateral agencies and international NGOs with the stated intention of bringing about various types of improvements in nations defined as "developing". I am not making any assumptions here about whether such endeavours actually can or do improve the wellbeing of populations, and I acknowledge that efforts may be based on false assumptions concerning local situations and histories (Ferguson, 1994) or falsely assumed compatibilities between economic "development", environmental sustainability and addressing poverty (Chapin 2004).

${ }^{2}$ It may also be useful to clarify the meaning of "theory", since this is so rarely done in the literature, suggesting that it is somehow obvious or that everyone shares the same meaning. Culler (1997) suggests that theory in the social sciences refers to "complex relations of a systematic kind among a number of factors". The existence of such relations is not obvious, hence the need for "theory", but since theories are not easily confirmed or disproved, there is plenty of room for controversy and the emergence of alternative theories relating to the same phenomena.
} 
bolstering local, perhaps unpopular governments (Ferguson, 1994). Although the insights arising from these critiques have been useful, contemporary issues in donor recipient countries, especially in Africa, seem to point to a lack of government, and a failure of aid to have an impact, rather than to the excessive interventions into peoples lives suggested by commonly applied theory.

\section{The problem of weak states}

The UK Department for International Development recently announced a shift in policy, placing increased emphasis on 'weak' and 'fragile' states (DFID, 2005a). A 'fragile state' is defined as one where 'the government cannot or will not deliver its basic functions ${ }^{3}$ to the majority of its people, including the poor (Ibid, p.7.) ${ }^{4}$

The rationale for this shift is that many poor people live in such states, and their poverty is partly caused by the failure of states to provide services. Fragile states 'affected by conflict or bad governance' ...'account for ....a third of those living in extreme poverty, half of children who are not in primary school and half of children who die before the fifth birthday' (DFID 2009: 69). ${ }^{5}$

Of crucial importance in this policy shift is the recognition of personal security as a felt need of the poor, which, if not adequately met by government, should be addressed by international aid agencies along with conventional 'basic needs' such as health and education. According to the Right Hon Hilary Benn, then Secretary of State for International Development:

"The poor...need security as much as they need clean water, schooling or affordable health. In recent years, DFID has begun to bring security into the heart of its thinking and practice" (DFID 2005b: Foreword).

And, according to a subsequent report:

"The poor themselves cite insecurity and powerlessness as some of the biggest impediments to a better life" (DFID 2009:75.).

Tackling poverty is DFID's mission, so avoiding weak and fragile states would be difficult to justify. However, their recent inclusion as priority targets for aid raises a number of issues and dilemmas.

\footnotetext{
${ }^{3}$ The same report defines these basic functions as follows: "The most important functions of the state for poverty reduction are territorial control, safety and security, capacity to manage public resources, delivery of basic services, and the ability to protect and support the ways in which the poorest people sustain themselves." (DFID 2005a:7).

${ }^{4}$ Although "there is no agreed global list of fragile states" (DFID, 2005a:7), DFID uses the World Bank's Country Policy and Institutional Assessments (CPIA), which generate five categories of performance, the lowest two of which are taken to indicate "fragile states". A further group of unranked countries bring the total list used in this report and listed in the Annex, to 46 countries. Examples of fragile states which are to receive increased DFID aid are Somalia, DRC and Afghanistan.

${ }^{5}$ A footnote to the 2009 report sources the statistics quoted from the World Bank Development Indicators database for 2009 and UNICEF States of the World's Children 2009 (for data on child mortality).
} 
First, emphasizing security as a development issue and working with states in conflict implies stronger links between 'development' and defence, and this is made explicit in recent policy documents (DFID 2005a, 2005b, 2009:71), where it is argued that:

"Development, defence and diplomacy need to work together. It is not possible to address present threats to human and global security without close collaboration" (DFID 2005:14).

The same report acknowledges that the objectives of security and development may conflict in particular contexts (DFID 2005:15), but also cites success stories (ibid:16).

DFID is not the only aid agency moving in this direction, and closer collaboration with partners, including the EU, UN and World Bank are included in the new strategy (DFID 2009:84). NGOs have already voiced concern as their personnel are exposed to attack by local people who have come to associate any form of aid with the military, particularly in the context of the post 9/11 'war on terror'.

A second dilemma arises from the acknowledgement that working with states displaying 'poor governance' contradicts the previous policy of 'good governance'. According to this policy adopted by many aid agencies in the $1990 \mathrm{~s}$, aid was conditional upon recipient governments' performance, particularly in terms of accountability and transparency. Although accountability in the use of funds does not necessarily imply effective delivery of services to the poor, the removal of accountability conditionality exposes DFID to accusations of 'throwing good money after bad'. If a government is incompetent in service delivery, why should they be any more effective in the utilization of donor funds? In recognition of this dilemma, DFID uses the term 'good enough governance' to specify certain minimum requirements in contexts where 'good governance' would rule out too many 'fragile states' (DFID 2005a, p.20).

Despite these misgivings, the policy does at least draw attention to the problem of weak government in a number of 'developing' nations, particularly in Africa. Furthermore, donors are increasingly aware of the need to understand the local political economy, especially in the context of weak and fragile states (DIFD 2005a, p.14). According to DFID:

"[T]he UK will increasingly put politics at the heart of its action. We need to understand who holds power in society, so we can forge new alliances for peace and prosperity....In the future, understanding political dynamics will shape more of our programmes. This will change the decisions we make about how we spend our aid budget, what we want to focus on and who we want to work with" (DFID 2009:73).

This shift provides an opportunity for anthropologists to play a role, through the application of relevant theory. However, my contention in this paper is that anthropological theory has not yet generated the analytical tools necessary for understanding 'weak' government. 


\section{Anthropological theory of the state}

Anthropologists have made productive use of Western European political theory and philosophy. In recent years Foucault has been especially influential, and his insights on power and government have been widely applied.

Foucault identified a tendency in European political history towards a particular mode of government, which took as its objective the wellbeing of the population. This involved a shift from earlier forms of government focused on the exercise of sovereignty over a territory. The 'art of government' which gradually emerged from the beginning of the $16^{\text {th }}$ century involved management of the relations between 'men and things', where 'things' refer to '....resources, territory....customs, habits, ways of acting and thinking, ... accidents, epidemics, and death.' (Foucault, 2009, p.96). This form of government depended on the development of statistics, which enabled the production of knowledge about a population, and of a set of governmental practices or techniques, which enabled interventions into the economy and into people's everyday lives.

Foucault used the label 'governmentality' to refer both to the set of capabilities which allowed for this mode of government, and to the historical tendency towards this form of government in the West. Foucault describes it in these terms:

"First, by "governmentality" I understand the ensemble formed by institutions, procedures, analyses and reflections, calculations, and tactics that allow the exercise of this very specific, albeit very complex, power that has the population as its target, political economy as its major form of knowledge, and apparatuses of security as its essential technical instrument. Second, by "governmentality" I understand the tendency, the line of force, that for a long time, and throughout the West, has constantly led towards the pre-eminence over all other types of power - sovereignty, discipline, and so on - of the type of power that we can call "government" and which has led to the development of a series of specific governmental apparatuses...on the one hand, [and on the other] to the development of a series of knowledges" (2009:108).

Foucault referred to this trend as the 'governmentalization' of the state (ibid, p.109). Although Foucault himself found the tendency towards increased 'governmentality' troubling (Burchell 1991:3) his purpose was not to critique government but to understand how it operates through specific practices in particular times and places.

Foucault drew on earlier social theorists, notably Weber, but he was careful to dissociate himself from political scientists, including Marxists, who regarded the state as somehow separate from and acting on society. This view has tended to give rise to 'state phobia' or the idea that the state has an inherent tendency to expand in scale and scope (Foucault 2009:109 \& 2008:76). By contrast, Foucault's concept of government referred to forms of power, or ways of shaping behaviour, exercised through a wide range of institutional forms, including the family, schools, prisons and so on. Indeed he was particularly interested in the relationships between forms of self-government, government of others and government by the state (Foucault 1983, 2008, 2009; Burchell 1991:4). 
Are Foucault's insights on power and government, which arose out the analysis of relatively strong states in Western Europe, equally relevant to the analysis of contemporary weak or fragile states in other regions? Is there a need for new theory to address these contemporary experiences?

Foucault's term 'governmentality' has been so widely applied in the anthropological literature that its meaning has tended to be diluted (Barnett 2005). It is almost as if any action by a contemporary government anywhere can be cited as an example of 'governmentality'. For example, Hammond (2008) describes the Ethiopian government's resettlement of vulnerable populations in Ethiopia as 'governmentality' even though she argues that it renders these populations invisible, rather than more amenable to 'government'. Paradoxically, despite Foucault's attempts to dissociate himself from 'state phobia,' the concept of governmentality appears to have fuelled this attitude among some analysts. The ongoing suspicion of social scientists towards 'the state' may explain the failure of anthropologists to build theory relevant to 'weak' states.

In the following sections I draw on my own field experience to explore the applicability of a Foucaultian lens in two contrasting countries: Indonesia and Ethiopia.

\section{Governmentality in Indonesia}

I have lived in Indonesia for five years, working on two assignments. While carrying out research on the private rice market for a food security project funded by DFID I lived in villages in West Java, East Java and South Sulawesi in the late 1980s. A decade later I researched relations between patients and health service providers in West Java for the World Bank.

In many ways the state in Indonesia epitomises the Foucaultian concept of governmentality and extends its relevance to a nation undergoing 'development'. This is reflected in the name Suharto used to describe his style of government, which ran from 1967 to 1998: the New Order. The term is evocative both of the Javanese cultural valuation of social order as reflecting the divine order of the cosmos, and of a decisive break with the chaotic violence following the military coup of 1965, which, ironically, brought Suharto to power, and during which half a million or more 'communists' were massacred (Pemberton 1994).

Suharto defined 'development' ('pembangunan', literally 'building') as a national project that would benefit everyone. Since, within this ideology, individual interests were perfectly aligned with national interests, 'national development' justified government penetration into every sphere of life (Antlov 1996:73; Burchell 1991:10). Just as Foucault described in the context of Western Europe, so in Indonesia this required the deployment of particular forms of knowledge and government techniques and apparatuses. The New Order's ability to do this was bolstered by income from oil (Hefner 1990) as well as extensive support from the international aid community, particularly in the US. 
Typical of these national programs has been the successful "dua anak cucup" or "two children are enough" family planning program. This attempt to control reproductive behaviour in the interests of national development ${ }^{6}$ was effected through a network of village level organizations, the $\mathrm{PKK}^{7}{ }^{7}$ which was, in effect, the women's branch of the local village development organization (LKMD) ${ }^{8} .{ }^{9}$ Under the New Order government PKK were replicated in all 70,000 villages, with all married women expected to be members, to attend meetings and to undertake programs of social work in their communities (Newberry 2006:13). The family planning program was one of the key programs undertaken by the PKK. Although not actually forced upon the population, the two child policy was certainly hard to avoid! During my fieldwork in the late 1990s many agreed that a two child family was 'good', while some appeared embarrassed at admitting to having larger families, suggesting that the policy had been internalized.

Foucault's description of 'governmentality' as a tendency towards the comprehensive government of 'relations between men and things' (Foucault 2009:96-108) resonates with my experience of living in an Indonesian village. The presence of government was palpable. Each new activity required permission from the village head, transformed by the New Order government from a local representative to an agent of the state (Antlov 1996; Newberry 2006). If you wished your child to go to school, you needed a letter from the village head. If you qualified for free health services, you needed a letter from the village head. Woe betide anyone who fell out with the village head!

The concept of the health centre 'working area' (wilayah kerja) illustrates the ambitions of the government to penetrate everyday life and the potential this holds both for improving service provision and for controlling people. In the following interview exert, a midwife at a Health Centre in West Java describes her interpretation which is typical of other health staff interviewed:

"Aside from the services in the puskesmas (health centre), we are supposed to monitor the health of the population in our administrative area. This is the 'wilayah kerja" ${ }^{10}$ concept. Even if someone never uses our services, we are considered responsible if something goes wrong in our district. Although we don't attend all deliveries, we [midwives] are supposed to be aware of all pregnant women, even those who never use our midwifery services. None of them should be missed, that is the ideal. I'm very keen that village midwives should detect pregnancies early on, during the first trimester. Sometimes they miss this opportunity. They are supposed to collect data every three months. The Posyandu ${ }^{11}$ is a good opportunity [for surveillance]. When the Posyandu is

\footnotetext{
${ }^{6}$ An example of what Foucault referred to as 'biopolitics' (Foucault 2008)

${ }^{7}$ PKK stands for pembinaan keluarga kesejahteraan", literally, guidance for prosperous families.

${ }^{8}$ LKMD is Lembaga Ketahanan Masyarakat Desa or Institution for the maintenance of village society (Newberry 2006:15).

${ }^{9}$ Both organizations were described by the government as 'grass roots' although state sponsored, obligatory and headed by the village head's wife (PKK) and the village head (LKMD) (Newberry 2006).

${ }^{10}$ Literally, "working area," but the meaning is closer to "area of responsibility" or "administrative area".

${ }^{11}$ The Posyandu is a monthly community health monitoring meeting for mothers of children under five years old, and pregnant women. It is attended by a health volunteer and, at least in theory, by staff from
} 
over, we ask the health volunteers: are there any pregnant woman around their houses? Has any woman missed her period? Anyone feeling nausea? If she hasn't visited the Posyandu, we have to visit her at her house. Maybe she is reluctant to come to be examined, or she is afraid of the cost, or she is just ignorant - if they have been checked by a TBA ${ }^{12}$ and the TBA says it is OK, nothing is wrong, they believe the TBA."

This attitude epitomizes the ideal relationship between government and the governed as conceived under the New Order: health staff should know when a woman misses her period, and women should attend the Posyandu monthly check-up. In this way, women will benefit from the health services, and the government will benefit from improved health statistics on infant and maternal mortality and on family planning. Individual and state interests are perfectly aligned.

\section{Popular responses to New Order forms of government}

The governmentality framework is useful as long as it does not obscure differences between Indonesian and Western European experiences. In Indonesia the New Order style of government, although in many ways similar to Foucault's description of governmentality in Western Europe, has been grafted onto a very different history. A fundamental aspect of this history lies in the hierarchical nature of social relations according to which "little people" are perceived to be powerless in relation to government officials. This history frames popular responses to government.

Many people I worked with had negative experiences with government health services, both in terms of the manner in which they were treated by health staff and in terms of the medical outcomes of services delivered. But I rarely encountered any attempt to communicate this dissatisfaction directly, either to the health centre or to any other government representative. The most typical response was to turn to an alternative provider, whether a private medical practitioner, a 'traditional' healer, or one of the many practitioners combining several 'traditions', with or without formal qualifications. The comments of one patient at a Health Centre in West Java are typical:

"I haven't told anyone at the health centre about my suggestions. I wouldn't know who to go to. I wouldn't dare to make a complaint. I'd be afraid if I make a complaint and ask for improvement I will be disliked and then it will affect my treatment. I can't talk freely to the health volunteers and I do not know any village representatives."

People were reluctant to complain not only because they thought it might jeopardize their future reception at the health centre, but because they needed to maintain a good reputation with the village head and other government officers in order to maintain access to a whole range of government services. According to an elected neighbourhood leader:

the Puskesmas. Children are weighed, vaccinations are given and a meal, food items or food supplements may be provided.

12 TBA = Traditional Birth Attendant. 
"As an apparatus of the government, I am often squeezed between the people and the government's interest. If there is any complaint and I forward it, I am afraid there will be some consequences, but if I do not forward it I will disappoint people, so please I hope the discussion will not go beyond these walls."

However, this fear of consequences or of conflict does not mean that Indonesians are simply passive recipients of government. ${ }^{13}$ Expressions of dissatisfaction tend to be channelled via the community, rather than by individuals. This sentiment is expressed by a neighbourhood leader from West Java:

"If there were a complaint about the service I would have to be sure that the community all agreed. I would not take the complaint to the kecamatan [subdistrict level] until I was sure that everyone in my area supported me. Otherwise it would cause division in my area. I'm the head of this neighbourhood. I represent the people in my area. First I would discuss the matter with them. Then, only when we had reached agreement would I go to the kecamatan with the complaint."

Governmentality Indonesia style has not been missed by anthropologists. A number of recent ethnographies explore different aspects of the New Order government's penetration into the daily lives of the Indonesian people and formation of 'modern' citizens. In The Will to Improve Tania $\mathrm{Li}$ focuses on attempts to 'modernize' agricultural systems through transmigration programs and the expansion of irrigated rice farming in Sulawesi (Li 2007). Jan Newberry (2006) focuses on the domestic sphere:

"PKK places working class housewives at the forefront of developing Indonesia. As a result the domestic activities of women and their roles in community have become, in a sense, a form of governmentality, an extension of government programs aimed at social welfare through the informal and formal labour of women and hence the extension of a rationality of self-management in aid of producing self-regulating, moral communities that are modernizing" (Newberry 2006:18).

Pemberton (1994) describes how the New Order government encouraged Indonesians to integrate 'traditional culture' into their daily lives, allegedly as a bulwark against the ills of Western civilization. In practice "culture" served both to legitimize Suharto's ${ }^{14}$ authority and to divert energies away from overtly political activity. Culture thus served to 'make people governable' in what Pemberton describes as a 'security state.'

\footnotetext{
${ }^{13}$ Although Pemberton (1994) argues convincingly that the New Order government was effective at limiting protest through diverting 'political' activity into 'cultural' activity.

${ }^{14}$ The Suhartoes presented themselves as quasi-royalty, imitating Javanese court culture, for example in the wedding of their daughter (Pemberton 2004:178).
} 
Just as Pemberton explored the 'culture effect' Ferzacca examined the 'medicine effect,' arguing that the New Order government promoted 'traditional medicine' as a remedy for the ills of modernity. People are encouraged to adopt breastfeeding, fasting and taking tonics (jamu), practices which are promoted as both traditional and modern. All of these analyses suggest that Foucaultian governmentality is alive and well in Indonesia's New Order government, albeit with a particularly Indonesian flavour.

\section{Sovereignty in Ethiopia}

"When the sun goes down the government, any government, is far, far away" Southern Sudanese, BBC World Service.

I am not so confident of the usefulness of a Foucaultian approach to the state in the Horn of Africa. I lived and worked in Ethiopia for three years, from 2004-2007, researching linkages between HIV, disability and access to water and sanitation for WaterAid, a UK based international NGO. I found little evidence of the government penetration into all aspects of daily life which I had experienced in Indonesia. Similarly absent were visions of a distinct Ethiopian modernity or explicit projects of citizen formation so familiar to Indonesians. Government was more often experienced in terms of a failure to provide expected basic services. The sector in which I worked was no exception.

Ethiopia has some of the worst health statistics in the world, and access to water and sanitation facilities is among the lowest (Ayele 2005). About $86 \%$ of the population live in rural areas (Bevan 2006; Watson 2005), and many of those living in remote villages have not yet made the connection between poor sanitation and the high incidence of infectious diseases and infant mortality

"In rural areas most people still practice open defecation, a tradition that has remained widespread through a lack of hygiene awareness and technical knowledge on the part of villagers and inadequate policy, investment and implementation on the part of the state." (Ayele 2005:1).

In the popular imagination life in remote, rural areas has changed little since ancient times, except that life has become harder due to increased population and more frequent drought. Whether or not this is so, the general impression is of a lack of government penetration, (with the possible exception of the security forces), beyond the capital and other major cities.. Although the Ministry of Health is committed to improving population health, its reach is limited by the lack of information, infrastructure and budgets necessary for effective service delivery to remote areas. Government is therefore limited by the absence of what Foucault described as the 'apparatuses and knowledges' of government (Foucault 2009:108). According to Howard:

"[C]urrent levels of staffing are considerably below the recommended guidelines. For example, the Water Resources Office in Hitosa has only one part-time staff member compared to the recommended number of eleven staff. 
The recurrent budget would have to expand by more than ten times just to cover staffing costs" (Howard 2005:2).

Government services are expanding, particularly in education. But despite the existence of a modern style bureaucratic civil service, in some respects the current government of Meles Zinawi displays elements of Foucault's 'sovereign state'. In a sovereign state the government is mainly concerned with maintaining control over a territory and its inhabitants, and only secondarily concerned with the needs of the population (Foucault, 2009). ${ }^{15}$

Zinawi's tendency towards a 'sovereign' style of government emerged during the aftermath of the contested 2005 'democratic' elections. During this period I witnessed the dilemmas faced by the international donor community as UK Prime Minister Tony Blair's 'democratic' African leader revealed despotic tendencies in refusing to accept the results of the 2005 elections. Meles Zenawi was only able to hold on to power in the face of widespread opposition through the use of force. Although Zenawi's government had used violence before, the threshold for its use was lowered following the 2005 elections. Public access to information was simultaneously curtailed through the suppression of the media. One is reminded of a sort of 'Emperor's new clothes' in reverse, as Zenawi's democratic credentials were exposed to be an illusion of the international community.

Despite public expectations for change, evidenced in the jubilantly optimistic election rallies held in the street where I was living, Zenawi's response was not entirely unexpected. He was able to draw on an authoritarian style of government with historical roots spanning the widely different ideological frameworks of the Emperors' autocratic paternalism, and of the Derg's socialist regime. The latter relied heavily on coercion to implement a Soviet style planned economy, overthrown by Zinawi in 1991. It is important to point out that Zinawi also relied on US support to remain in power. The Bush government saw him as an ally in the 'war on terror' and US diplomatic support complicated attempts by the donor community to signal disapproval of his post-election behaviour. Initial plans by a number of donors to freeze aid were compromised. In the end, aid was simply shifted from the central government and channelled directly to local government.

References to governmentality in Ethiopia tend to refer to specific locations (Ellison 2009) or programmes (Hammond 2008). These analyses do not portray an all pervasive government whose presence extends to the hinterlands as one finds in Indonesia. On the contrary, Hammond argues that the resettlement program which she studied actually renders the poor who are resettled invisible, achieving the political aim of allowing the government to ignore them. Ellison, on the other hand, explores popular responses to the reductions in government service provision in sectors such as health and education that followed neoliberal reforms. Foucault analysed neoliberal forms of governmentality in his series of lectures titled 'The Birth of Biopolitics' (Foucault 2008). Since neoliberal ideology advocates reductions in the scale and scope of government, governmentality takes on more subtle forms, and government

\footnotetext{
${ }^{15}$ Foucault did not claim that sovereignty and governmentality styles of government were mutually exclusive. Elements of sovereignty were also apparent in Indonesia's New Order government, in its military repression in Aceh, East Timor and Western Papua, all justified as being in the interests of 'national development'.
} 
agency in subject formation becomes harder to detect, although no less real. However, in the Ethiopian case neoliberal governmentality as described by Ellison is not home grown, but rather imposed by international finance and aid organizations. As elsewhere, whether the reforms are adopted willingly or unwillingly, this represents a loss of state sovereignty (Zulaika 2010; Greenhouse 2010). Furthermore, small government is being introduced in nations which have never really had the sort of strong government in which neoliberal ideology has emerged. In countries such as Ethiopia, basic services are being cut back long before they have achieved universal coverage.

\section{The absence of local government in Lesotho}

Ironically, another country where I encountered weak government was Lesotho, the very country where Ferguson has suggested that development assistance extended the reach of government. Ferguson uses Lesotho as a case study to reveal how the 'development apparatus' operates as an 'anti-politics machine', undermining local political processes and depoliticizing poverty (Ferguson 1994:23, 251). But while Ferguson's analysis may apply to the Thaba Tseka region, where his case study project was based, the reach of government appears to be limited in other regions of this small, mountainous nation.

In Lesotho, I was employed by CARE International as a researcher on their project 'underlying causes of poverty in Lesotho'. The project drew attention to the way in which Lesotho's poverty was created historically through land appropriations and through its being forced into the role of a labour reserve, first by Dutch and British colonial powers, and then by the South African apartheid government. Gender inequity was identified as a second underlying cause. Most pertinent for this paper, though, is the third underlying cause, identified as weak governance. This included inadequate law and order, failure to deliver basic public services, ineffective local government, corruption and unstable political processes deterring investment (Turner 2005). Although all of these aspects of inadequate government were widely recognized by local people, and were frequently mentioned in consultations on poverty for the National Poverty Reduction Strategy Paper (Leboela and Turner 2003), Lesotho is not normally included among categorisations of 'fragile states'. This is not to argue that Ferguson was wrong, but it does highlight the amount of work required to extend effective government throughout a national territory and population.

The demand for effective government is highlighted by recent events around the world, including the stalled formation of a new government in Afghanistan and Iraq, the two month absence of Nigeria's president for medical treatment, and the destructive impact of an earthquake on Haiti's government buildings. In January 2010, young people in Nigeria were out in the streets demanding government as their right (BBC World Service).

\section{Do we need a new theory for 'weak government'?}


It could be argued that Foucault is still applicable in cases of weak government such as Ethiopia and Lesotho, since the predicament of people in these nations can be described in terms of the lack of governmentality, or, as I suggested in the case of Ethiopia, within Foucault's sovereignty model. But it seems to me that we may need a different theoretical framework which speaks more directly to the condition of people living in contemporary weak, fragile or failed states, which may not fit Foucault's sovereignty-discipline-governmentality model very well.

Ben Jones (2009) appears to reach a similar conclusion in relation to Uganda. Although regarded by the international community as a rare success story in African development, Jones found the government conspicuous by its absence in the rural area where he conducted fieldwork. In fact, government presence had actually reduced compared with previous decades. He contrasts the reality of 'no government' with the expectations raised both by Foucaultian analysis and by the vision of the 'development machine' perpetrated by Ferguson and others. He argues that these theoretical lenses encourage researchers to focus on the state and development agencies as the sole engines of change, while remaining blind to the experiences of many rural dwellers, who may turn to other institutions, in this particular case to the church, as a source of governance.

Weak government is not, of course, a new issue, ${ }^{16}$ and it has been addressed by anthropologists before. As Lewis and Mosse (2006) point out, anthropological theory has tended to address weak or ineffective states through the lens of patron-client relations. This framework continues to be relevant in some contemporary contexts. For example, in The Politics of the Governed Chatterjee describes the strategies adopted by squatters who are marginalized by the state due to their semi-legal status but nevertheless negotiate access via emergent middlemen to services which they feel entitled to (Chatterjee 2004). He suggests the term 'political society' to describe this type of popular politics, which he argues is prevalent although largely invisible, due to the unrecognized citizenship of its protagonists.

Another promising avenue is suggested by Scott in The Art of Not Being Governed, where he argues that people living in remote, mountainous regions, physically located at the periphery, may not be historically marginalized and "backward" so much as intentional fugitives from neighbouring states (Scott 2009). Based on his research of the region of 'Zomia', a mountainous area stretching from the central highlands of Vietnam to north-eastern India, and spanning five Southeast Asian nations and four provinces of China (ibid:i), he illustrates how people have elected to escape from state taxation, military conscription and other forms of control by adopting peripheral lifestyles. These included shifting cultivation (which is difficult to tax or control), segmentary social organization, and even the 'forgetting' of literacy. However, he argues that these populations and strategies have been dwindling since the Second World War due to the increased effectiveness of states, bolstered by information and security technologies.

The problem may not be so much a lack of theory as the knee jerk and universal application of 'overly systematic' interpretations of governmentality as a form of state

\footnotetext{
${ }^{16}$ Weak government in the contemporary context is likely to have been exacerbated not only by civil wars in a number of countries, by also neoliberal reforms aimed at reducing government expenditure and scope of action, carried out under pressure from international financial and aid institutions.
} 
action (Barnett 2005). Has 'governmentality' become what Geertz described as a 'grand idea', applied uncritically in all contexts (Geertz 1973)? Is it now time to 'cut governmentality down to size,' and can the development enterprise help us in this process?

\section{How can the development enterprise contribute to building new theory relevant to weak and fragile states?}

International development practitioners can contribute to theory building in anthropology in at least two important ways. Firstly, they can highlight contemporary issues which may not yet have impinged on the discipline of anthropology. An example of this is DFID's new policy focus on "weak" and "fragile" states. This should send alarm bells to anthropologists, both because it calls attention to the situation in these countries and because it signals trends in global governance which require careful monitoring.

A second contribution arises from development practitioners' daily encounters with government personnel as well as with the effects of weak government. These experiences can form the basis for theory building in anthropology, generating theory which could in turn benefit development workers. However, this will require a change in attitude on the part of some anthropologists.

Although the development enterprise has provided fertile ground for anthropological analysis, much of this has been critical (Gow 2002; Lewis 2005). Attention has focused on the hidden agendas and failings of 'development' (see for example Ferguson 1994, 1997; Escobar 1995; Esteva 1995; Mitchell 2002; Li 2007), which has been termed anthropology's 'evil twin' (Ferguson 1997). Many of these analyses draw on Foucaultian discourse analysis, and examine the relationship between knowledge, power, and subject formation. For example, Esteva argues that 'development' emerged in the post World War II era as a thin disguise for American global hegemony and the struggle against communism (Esteva 1992:6) ${ }^{17}$ Ferguson claims that it facilitates hidden political agendas, including the depoliticization of poverty and the extension of government power (1994); while Escobar, one of its most vocal critics, claims that it has failed entirely in terms of its stated objectives: "[T]he discourse and strategy of development produced its opposite: massive underdevelopment and impoverishment, untold exploitation and oppression" (Escobar, 1995:4).

The "deconstruction" of development poses an important challenge to a dominant framework, revealing how difficult it is to think outside of the development/modernity mind set. But these analyses rarely offer constructive suggestions (Gow 2002). Furthermore, and somewhat paradoxically, given the aims of the authors, by focusing attention on the development apparatus as Western intervention, attention is diverted from government practice and its challenges within recipient nations, which is surely not entirely driven by foreign agendas. One reason for the negative impression generated by these analyses of development may lie in their focus on broad historical

\footnotetext{
${ }^{17}$ Similar arguments continue to be made in relation to neoliberal reforms today (Zulaika, 2010), which have become the 'only show in town' following the fall of communism (Makhulu, 2010).
} 
overviews rather than on the daily experiences and world views of development practitioners. By listening to the experiences of development workers 'on the front line', and exploring how they make sense of the situations they find themselves in, anthropologists may be able to offer more than negative critique.

There are, in fact, an increasing number of quality ethnographies which do just this (Mosse 2005; Hilhorst 2003; Sridhar 2008). Ethnographies of individual organizations, projects and programmes offer a richer, more nuanced picture of 'development' which recognizes achievements as well as failures, and explores why and how outcomes may differ from the intended plans without always being bad outcomes. Some of these ethnographies have been undertaken by academics who have been personally involved in the programs they are studying (Mosse 2005; Hilhorst 2003). This can help to bridge the divide between 'applied' and 'theoretical' anthropology so eloquently described by Ferguson (1997), Gow (2002), Lewis (2005) and others.

Having set the trend for a productive form of analysis, perhaps it is now time to shift the focus of some of these "development" ethnographies away from the antics of the development agencies themselves and towards the challenges facing local government officials particularly in "weak and fragile" states. Given their access to government, often at local as well as regional and national levels, development practitioners are in a good position to generate alternative perspectives on the practice of government in these contexts.

\section{Conclusion}

In this paper I have tried to show how engagements with international development can highlight limitations in anthropological theory. Prevalent interpretations of Foucault's concept of "governmentality", although applicable in some cases, appear irrelevant in contexts commonly encountered by development workers, where people are suffering from a lack of government and are actively demanding greater government presence.

On the other hand, development practitioners' daily encounters with the practice of government provide a useful starting point for building new theory relevant to contemporary experience of weak government in some donor recipient nations. At the same time, it is important to recognize processes of "government" and of socioeconomic change occurring beyond the reach of development agencies and the state, both in "fragile" and "strong" states (Jones, 2009). This was, of course, a key element in Foucault's own research agenda.

Detailed ethnographies of the development encounter, including those undertaken by development practitioners themselves, can provide a foundation for building new theory to address contemporary issues, such as those faced by governments and the governed living in 'weak and fragile states'. Such studies can enrich our understanding of development processes, while helping to bridge the gap between 'applied' and 'theoretical' anthropology. 


\section{About the author}

Note on the author: Priscilla Magrath is enrolled in a $\mathrm{PhD}$ program in Medical Anthropology at University of Arizona, USA. This follows over 20 years' experience working in international development. Her dissertation research, focusing on client responsiveness and public accountability in the delivery of health services in Indonesia, involves an ethnography of a World Bank health project which the author worked on for several years.

\section{References}

Antlov, Hans 1996. Village leaders and the New Order. In Antlov, H. and Cederroth, S. eds. 1996. Leadership on Java: Gentle Hints, Authoritarian Rule, p.73-96. Curzon Press, Surrey, UK.

Ayele, Manyahishal. 2005. Water is Life, Sanitation is Dignity. Briefing Note 1, WaterAid, Ethiopia.

Barnett, Clive. 2005. The Consolations of 'Neoliberalism.' Geoforum 36, 2005, pp 712.

Bevan, Phillipa. 2006. Power and Social Policy in Development Contexts: Ethiopia's In/Security Regime. ESRC Wellbeing in Developing Countries Research Program University of Bath, UK. Prepared for delivery at the 2006 Annual Meeting of the American Political Science Association, August 30th - September 3rd, 2006.

Copyright by the American Political Science Association

Burchell, Graham. et al. ed. 1991. The Foucault Effect: Studies in Governmentality. Chicago, University of Chicago Press.

Chapin, Mac. 2004. A Challenge to Conservationists. Worldwatch Magazine, November/December, 2004. pps 17-31. Worldwatch Institute, Washington, DC.

Chatterjee, Partha. 2004. The Politics of the Governed: reflections on popular politics in most of the world. New York. USA. Columbia University Press.

Culler, John. 1997. Literary Theory: a very short introduction. Oxford. UK. Oxford University Press.

DFID. 2005a. Why we need to work more effectively in fragile states. January 2005. Department for International Development, UK.

DFID. 2005b. Fighting poverty to build a safer world. March 2005. Department for International Development, UK.

DFID. 2009. Eliminating World Poverty: Building our Common Future. July 2009. Department for International Development, UK. 
Ellison, James. 2009. Governmentality and the Family: Neoliberal choices and emergent kin relations in Southern Ethiopia. American Anthropolgist. Vol. 111. No.1 pp.81-92.

Escobar, Arturo. 1995. The Making and Unmaking the Third World. New Jersey, USA. Princeton University Press.

Esteva, Gustavo. 1992. 'Development' In Sachs, W. ed. The Development Dictionary. Pp. 6-25. London. Zed Books.

Farmer, Paul, 2001. Infections and Inequalities: The Modern Plagues. London. University of California Press.

Ferguson, James. 1994. The Anti-Politics Machine: "development", depoliticization, and bureaucratic power in Lesotho. Cambridge, UK. Cambridge University Press.

Ferguson, James. 1997. Anthropology and Its Evil Twin: "Development in the constitution of a discipline. In International Development and the Social Sciences: Essays on the History and Politics of Knowledge. Frederick Cooper and Randall Packard. eds. pp150-175. Berkeley: University of California Press.

Ferzacca, Steve. 2002. Governing Bodies in New Order Indonesia in Nichter, M. and Lock, M. ed. New Horizons in Medical Anthropology. pps 35-57. London and New York. Routledge.

Foucault, Michel. 1983. The Subject and Power. In Dreyfus and Rabinow: Michel Foucault: Beyond Structuralism and Hermeneutics. pps 208-225. Chicago. University of Chicago Press.

Foucault, Michel. 2008. Biopolitics. Lectures at the College de France 1978-79. Hampshire, UK. Palgrave Macmillan.

Foucault, Michel. 2009 Security, Territory, Population. Lectures at the College de France 1977-78. Hampshire, UK. Palgrave Macmillan.

Geertz, Clifford. 1973. The Interpretation of Cultures. New York. Basic Books.

Gow, David. 2002. Anthropology and Development: Evil Twin or Moral Narrative? Human Organization. Winter 2002; 61, 4, pps. 299-313.

Greenhouse, Caroline, ed. 2010. Ethnographies of Neoliberalism. Pennsylvania. University of Pennsylvania Press.

Hammond, Laura. 2008. Strategies of Invisibilization: how Ethiopia's resettlement program hides the poorest of the poor. Journal of Refugee Studies, Vol. 21, No. 4. pps.517-536. Oxford. Oxford University Press.

Hefner, Robert. 1990. Political Economy of Mountain Java: an interpretive history. California. University of California Press. 
Hilhorst, Dorothea. 2003. The Real World of NGOs. London. Zed Books.

Howard, Sarah 2005. Turning money into water: what sort of fiscal policy works for the water sector? Briefing Note 4, WaterAid, Ethiopia.

Jones, Ben. 2009. Beyond the State in Rural Uganda. Edinburgh. Edinburgh University Press.

Leboela, T. and Turner, Stephen. D. 2003. The Voice of the People: Report on community consultations for the National Vision and the Poverty Reduction Strategy Paper. Maseru. Ministry of Development Planning and UNDP.

Lewis, David. 2005. Anthropology and Development: the uneasy relationship [online]. London: LSE Reasearch Online. Available at:

http://eprints.Ise.ac.uk/archive/00000253.

Lewis, D. and Mosse, D. 2006. Brokers and Translators: the ethnography of Aid and Agencies. Virginia, US. Kumarian Press.

Li, Tania. 2007. The Will to Improve: governmentality, development and the practice of politics. Durham, North Carolina, US. Duke University Press.

Makhulu, Anne Maria. 2010. The Question of Freedom: Post-emancipation South Africa in a Neoliberal Age in Greenhouse, Caroline, ed. 2010. Ethnographies of Neoliberalism. pps.131-145, Pennsylvania. University of Pennsylvania Press.

Mitchell, Timothy. 2002. Rule of Experts: Egypt, techno-politics, modernity. California, US. University of California Press.

Mosse, David. 2005. Cultivating Development: An Ethnography of Aid Policy and Practice. London. Pluto Press.

Newberry, Jan. 2006. Backdoor Java: state formation and the domestic in working class Java. Ontario, Canada. Broadview Press.

Pemberton, John. 1994. On the Subject of Java. Ithaca, New York. Cornell University Press.

Scott, James C. 1998. Seeing Like a State: how certain schemes to improve the human condition have failed. New Haven, Connecticut, US. Yale University Press.

Scott, James C. 2009. The Art of Not Being Governed: an anarchist history of upland South East Asia. New Haven, Connecticut, US. Yale Universtiy Press.

Sridhar, Devi. 2008. The Battle Against Hunger: choice, circumstance and the World Bank. Oxford, UK. Oxford University Press.

Turner, Stephen. 2005. The Underlying Causes of Poverty in Lesotho. CARE Lesotho-South Africa. http://www.caresa- 
lesotho.org.za/documents/Underlying\%20causes\%20of\%20poverty\%20in\%20Lesoth o.pdf

Watson, Cathy. 2005. Exploring urban myths: poverty, water and sanitation in the city. Briefing Note 5, WaterAid, Ethiopia.

Zulaika, Joseba. 2010. The War on Terror and the Paradox of Sovereignty: declining states and states of exception. In Greenhouse, Caroline, ed. 2010. Ethnographies of Neoliberalism. pps. 28-43. Pennsylvania, US. University of Pennsylvanis Press. 